\title{
STABILITAS PRC DALAM LARUTAN ALSEVER BUATAN TERHADAP MORFOLOGI ERITROSIT DAN FRAGILITAS OSMOTIK
}

\author{
Fauziyah, Zhahrina'; Hayati, Eem ${ }^{1}$; Nurhayati, Betty ${ }^{1}$; Marliana, Nina ${ }^{1}$ \\ ${ }^{1} J u r u s a n$ Analis Kesehatan Poltekkes Kemenkes Bandung \\ e-mail: zhahrina.f@gmail.com
}

\begin{abstract}
ABSTRAK
Penyimpanan sel darah merah (eritrosit) dalam media pengawet berkaitan dengan penurunan ATP pada eritrosit hingga $80-90 \%$, menyebabkan perubahan morfologi dan meningkatkan fragilitas osmotik. Larutan Alsever memiliki fungsi sebagai pengawet darah yang mengandung larutan garam isotonik untuk mempertahankan keseimbangan sel. Tetapi, larutan Alsever sulit didapatkan karena harganya cukup mahal, sehingga sebagai alternatif dapat membuat larutan Alsever sendiri. Penelitian ini bertujuan untuk mengetahui stabilitas PRC dalam larutan Alsever buatan terhadap morfologi eritrosit dan fragilitas osmotik. Jenis penelitian ini adalah desain quasi eksperimen yang membandingkan antara metode penyimpanan PRC menggunakan larutan Alsever buatan sendiri dengan metode penyimpanan PRC menggunakan larutan Alsever komersial selama 15, 20, 25, 30 hari terhadap stabilitas morfologi eritrosit dan fragilitas osmotik. Indikator yang dilihat dari perubahan morfologi yaitu terbentuknya echinocytes dan crenated cell. Setelah diuji secara statistik dari hasil penelitian dapat ditarik kesimpulan bahwa terdapat pengaruh antara lama penyimpanan PRC dalam Alsever Buatan terhadap morfologi eritrosit dan fragilitas osmotik. Pada pemeriksaan morfologi eritrosit dan fragilitas osmotik PRC dalam Alsever Buatan stabil hingga hari ke-15 dan mulai terdapat perbedaan signifikan pada penyimpanan hari ke-20, sedangkan PRC dalam Alsever Komersial stabil hingga hari ke-20 dan mulai terdapat perbedaan signifikan pada penyimpanan hari ke-25.
\end{abstract}

Kata Kunci: PRC, Alsever Buatan, Morfologi Eritrosit, Fragilitas Osmotik

\begin{abstract}
Storage of red blood cells (erythrocytes) in preservative media is associated with a decrease in ATP in erythrocytes up to $80-90 \%$, causes morphological changes and increase osmotic fragility. Alsever solution has a function as a blood preservative containing an isotonic salt solution to maintain cell balance. However, Alsever's solution is difficult to obtain because the price is quite expensive, so as an alternative it can make Alsever's own solution. Therefore, this study was conducted which aims to determine the stability of PRC in artificial Alsever solutions to erythrocyte morphology and osmotic fragility. This study uses a quasi-experimental design that compares the PRC storage method using artificial Alsever solution with the PRC storage method using commercial Alsever solution for 15, 20, 25, 30 days from erythrocyte morphological stability and osmotic fragility. The indicators seen from morphological changes are the formation of echinocytes and crenated cells. After being statistically tested from the results of the study it can be concluded that there is an influence between the length of storage of PRC in Artificial Alsever on the erythrocyte morphology and osmotic fragility. On the morphological examination of erythrocytes and the osmotic fragility of PRC in Artificial Alsever stabilized until the $15^{\text {th }}$ day and there began to be a significant difference in the storage of the $20^{\text {th }}$ day, while the PRC in the Commercial Alsever was stable until the $20^{\text {th }}$ day and began significant differences in the storage of the $25^{\text {th }}$ day.
\end{abstract}

Key words: Packed Rec Cell, Artificial Alsever, Erythrocyte Morphology, Osmotic Fragility 


\section{PENDAHULUAN}

Penyimpanan sel darah merah (eritrosit) dalam media pengawet berkaitan dengan perubahan struktur metabolik, biokimia, dan biomekanik molekul pada eritrosit, seperti perubahan bentuk, deformabilitas, fragilitas osmotik, kemampuan untuk agregasi, dan viskositas intraseluler, dimana secara kolektif disebut sebagai "lesi/jejas penyimpanan". ${ }^{1,2}$ Kerusakan yang paling mungkin adalah protein sitoskeletal pada membran eritrosit. ${ }^{3}$ Perubahan tersebut akan menyebabkan eritrosit menjadi rapuh dan meningkatkan kerapuhan osmotik dan perubahan ketidakseimbangan elektrolit. Penurunan ATP pada eritrosit dapat hingga $80-90 \%$ selama penyimpanan dan menyebabkan perubahan morfologi. Sejumlah besar sferosit menjadi irreversible/tidak dapat berubah. ${ }^{4,5}$ Namun, beberapa kerusakan lainnya tidak dapat dipulihkan secara spesifik termasuk peningkatan kerapuhan osmotik, eritrosit kaku perubahan dari bentuk bikonkaf menjadi echinocytic kecil dengan tonjolan dan penurunan fungsi, microvesiculation, dan hemolisis. ${ }^{6}$

Penyimpanan PRC yang benar merupakan salah satu cara menjaga kualitas eritrosit. ${ }^{7}$ PRC dapat disimpan sekitar 35-42 hari tergantung larutan antikoagulan atau pengawet yang digunakan untuk mencegah pembekuan darah atau koagulasi selama masa penyimpanan. ${ }^{8}$ Larutan Alsever memiliki fungsi sebagai pengawet darah yang mengandung larutan garam isotonik untuk mempertahankan keseimbangan sel. Kemampuan larutan ini bermanfaat dalam membantu kehidupan antigenik eritrosit, sehingga sel dapat bertahan hidup dalam jangka waktu yang lama. ${ }^{9}$ Namun, larutan Alsever sulit didapatkan karena harganya cukup mahal, sehingga sebagai alternatif dapat membuat larutan Alsever sendiri.

Menurut Aulia Hanum $^{10}$ pada penelitian sebelumnya tahun 2018 menunjukkan hasil bahwa kadar hemoglobin, hematokrit, jumlah eritrosit, nilai $\mathrm{MCV}, \mathrm{MCH}$ dan $\mathrm{MCHC}$ dalam PRC pada larutan Alsever komersial dan buatan, stabil hingga penyimpanan hari ke-20. Sehingga dalam penelitian ini penulis akan meneliti stabilitas PRC yang disimpan selama lebih dari 20 hari.

Penelitian ini bertujuan untuk mengetahui ada tidaknya pengaruh lama penyimpanan PRC dan stabilitas PRC dalam larutan Alsever buatan terhadap morfologi eritrosit dan fragilitas osmotik.

\section{METODE}

Jenis penelitian ini adalah desain quasi eksperimen yang menggunakan studi perbandingan dengan cara membandingkan antara metode penyimpanan PRC menggunakan larutan Alsever buatan sendiri dengan metode penyimpanan PRC menggunakan larutan Alsever komersial selama 15, 20, 25, 30 hari yang kemudian dilakukan pemeriksaan terhadap stabilitas morfologi eritrosit dan fragilitas osmotik dalam masingmasing pengulangan 5 kali dengan subjek penelitian darah normal.

Penelitian ini dilaksanakan di Laboratorium Hematologi Politeknik Kesehatan Kementerian Kesehatan Bandung yang dimulai pada bulan Maret hingga April 2019. Pemeriksaan Morfologi Eritrosit dilakukan secara mikroskopis menggunakan SADT (Sediaan Apus Darah Tepi) dengan pewarnaan Giemsa dan pemeriksaan Fragilitas Osmotik dilakukan menggunakan metode Sanford secara kualitatif.

Data yang digunakan dalam penelitian ini merupakan data primer yang didapatkan dari hasil pengamatan morfologi eritrosit dan fragilitas osmotik, sebagai pengaruh dari variasi lama penyimpanan PRC dalam larutan Alsever pabrikan dan larutan Alsever buatan sendiri, kemudian data ditampilkan dalam bentuk tabel pada lampiran data hasil pemeriksaan. 
Pengolahan dan analisis data untuk memperoleh stabilitas morfologi eritrosit dan fragilitas osmotik diolah menggunakan uji statistik One-Sample Kolmogorov-Smirnov Test, selanjutnya dilakukan uji tes General Linear Model
(GLM) - Repeated Measures dengan cara membandingkan hasil pengukuran dengan pengukuran awal pada setiap parameter. Kemudian dilakukan uji Wilcoxon test sebagai alternatif pengganti uji Paired Sample T Test. ${ }^{11}$

\section{HASIL}

\section{Morfologi Eritrosit}

Pada penelitian ini analisis eksperimen dikaji dengan perhitungan jumlah bentuk abnormal eritrosit, yaitu crenated cell dan burr cell/echinocyte yang diamati dalam 1000 eritrosit normal dengan menggunakan perbesaran 100x secara mikroskopis. Pengamatan dilakukan oleh 1 orang peneliti dan 1 orang verifikator dari tim ahli. Data hasil perhitungan eritrosit abnormal tertera dalam tabel 1.

Tabel 1. Data Hasil Perhitungan Eritrosit Abnormal dalam Alsever Buatan dan Komersial

\begin{tabular}{|c|c|c|c|c|c|c|c|c|c|}
\hline \multirow{3}{*}{ Pengulangan } & \multirow{3}{*}{ Pengamat } & \multicolumn{8}{|c|}{ Jumlah Eritrosit Abnormal $(\%$} \\
\hline & & \multicolumn{4}{|c|}{ Alsever Komersial } & \multicolumn{4}{|c|}{ Alsever Buatan } \\
\hline & & $\begin{array}{c}15 \\
\text { hari }\end{array}$ & $\begin{array}{c}20 \\
\text { hari }\end{array}$ & $\begin{array}{l}25 \\
\text { hari }\end{array}$ & $\begin{array}{c}30 \\
\text { hari }\end{array}$ & $\begin{array}{c}15 \\
\text { hari }\end{array}$ & $\begin{array}{c}20 \\
\text { hari }\end{array}$ & $\begin{array}{c}25 \\
\text { hari }\end{array}$ & $\begin{array}{l}30 \\
\text { hari }\end{array}$ \\
\hline \multirow{2}{*}{1} & Pengamat 1 & 19 & 26 & 26 & 82 & 26 & 51 & 83 & 196 \\
\hline & Verifikator & 21 & 27 & 27 & 82 & 26 & 52 & 84 & 197 \\
\hline \multirow{2}{*}{2} & Pengamat 1 & 24 & 24 & 26 & 82 & 28 & 52 & 83 & 182 \\
\hline & Verifikator & 25 & 23 & 26 & 77 & 29 & 56 & 82 & 179 \\
\hline \multirow{2}{*}{3} & Pengamat 1 & 13 & 19 & 31 & 79 & 28 & 50 & 92 & 168 \\
\hline & Verifikator & 15 & 21 & 31 & 73 & 27 & 47 & 94 & 182 \\
\hline \multirow{2}{*}{4} & Pengamat 1 & 15 & 25 & 29 & 78 & 21 & 48 & 96 & 177 \\
\hline & Verifikator & 15 & 25 & 30 & 80 & 24 & 50 & 92 & 184 \\
\hline \multirow{2}{*}{5} & Pengamat 1 & 12 & 22 & 24 & 70 & 22 & 49 & 98 & 196 \\
\hline & Verifikator & 12 & 23 & 25 & 70 & 21 & 49 & 96 & 189 \\
\hline
\end{tabular}

Berdasarkan data hasil perhitungan eritrosit abnormal pada PRC dalam Alsever Komersial maupun Alsever Buatan di atas menunjukkan bahwa ditemukannya bentuk crenated cell dan echinocytes dengan jumlah satuan $(\% 0)$ yang telah tertera pada tabel 1. Jumlah crenated cell dan echinocytes mengalami peningkatan pada PRC yang disimpan selama 30 hari, dimana hal ini berarti semakin lama penyimpanan PRC dalam Alsever Komersial dan Alsever Buatan dapat mengakibatkan peningkatan jumlah crenated cell dan echinocytes. Semakin lama penyimpanan, bentuk echinocytes berubah menjadi sphero-echinocytes. Bentuk echinocytes sudah muncul pada penyimpanan hari ke-15 dan bentuk sphero-echinocytes ditemukan lebih banyak pada penyimpanan hari ke-25.

\section{Fragilitas Osmotik}

Analisis eksperimen lainnya yang dikaji pada penelitian ini adalah pemeriksaan fragilitas osmotik atau resistensi osmotik dengan hasil yang diperoleh merupakan persen hemolisis untuk tiap-tiap konsentrasi $\mathrm{NaCl}$ yang telah ditentukan. Hasil perhitungan persentase hemolisis tertera pada tabel 2. 
Tabel 2. Hasil Perhitungan Persen Hemolisis Pada Pemeriksaan Fragilitas Osmotik

\begin{tabular}{ccccccccc}
\hline & \multicolumn{7}{c}{ Resistensi Maksimum (\%) } \\
\cline { 2 - 9 } Pengulangan & \multicolumn{7}{c}{ Alsever Buatan } \\
\cline { 2 - 9 } & 15 Hari & 20 Hari & 25 Hari & 30 Hari & 15 Hari & 20 Hari & 25 Hari & 30 Hari \\
\hline 1 & 0,32 & 0,32 & 0,38 & 0,38 & 0,38 & 0,38 & 0,40 & 0,42 \\
\hline 2 & 0,32 & 0,32 & 0,38 & 0,38 & 0,36 & 0,38 & 0,40 & 0,40 \\
\hline 3 & 0,32 & 0,34 & 0,38 & 0,38 & 0,36 & 0,38 & 0,40 & 0,42 \\
\hline 4 & 0,32 & 0,32 & 0,38 & 0,40 & 0,36 & 0,38 & 0,38 & 0,40 \\
\hline 5 & 0,32 & 0,32 & 0,38 & 0,38 & 0,36 & 0,38 & 0,40 & 0,40 \\
\hline Rerata & 0,32 & 0,324 & 0,38 & 0,384 & 0,36 & 0,38 & 0,398 & 0,41 \\
\hline
\end{tabular}

Berdasarkan tabel 2 di atas menunjukkan bahwa terjadi peningkatan fragilitas osmotik ditandai dengan resistensi maksimum yang semakin lama penyimpanan PRC dalam Alsever Komersial maupun Alsever Buatan mengalami penurunan resistensi atau berarti penurunan daya tahan eritrosit dalam larutan hipotonis. Peningkatan kerapuhan membran eritrosit dapat dilihat dari grafik tersebut dengan satuan persen (\%) hemolisis dengan konsentrasi $\mathrm{NaCl}$. Pada hari ke-15 didapatkan rata-rata resistensi maksimum pada PRC dalam Alsever Komersial yaitu $0,32 \%$, kemudian hari ke-20 meningkat tidak terlalu jauh dengan rata-rata resistensi maksimum $0,324 \%$, hari ke-25 diperoleh rata-rata resistensi maksimum $0,38 \%$, dan pada hari ke-30 didapatkan rata-rata resistensi maksimum 0,384\%.

Sedangkan rata-rata resistensi maksimum pada PRC dalam Alsever Buatan penyimpanan hari ke-15 diperoleh $0,36 \%$, hari ke-20 yaitu $0,38 \%$, hari ke-25 yaitu 0,398 , dan pada hari ke-30 diperoleh rata-rata resistensi maksimum sebesar 0,41\%. Hal ini menunjukkan bahwa rata-rata resistensi maksimum pada PRC dengan Alsever Buatan mengalami peningkatan dalam 4 variasi waktu simpan tersebut, begitu juga pada PRC dengan Alsever Komersial.

Peningkatan fragilitas osmotik tersebut menandakan bahwa adanya penurunan stabilitas membran eritrosit dengan meningkatnya resistensi maksimum dan tidak diketahui resistensi minimumnya.

\section{PEMBAHASAN}

Penelitian ini menemukan bahwa terdapat hubungan antara variasi lama penyimpanan dengan peningkatan perubahan morfologi eritrosit (crenated cell dan echinocytes), begitupun setelah dievaluasi menggunakan uji statistik GLM-Repeated Measures formasi morfologi eritrosit terdapat perbedaan yang signifikan seiring dengan semakin lamanya waktu penyimpanan. Hal ini sesuai dengan hasil sebelumnya. $^{12,13}$ penelitian-penelitian

Selama penyimpanan, perubahan morfologi eritrosit pada PRC menjadi crenated cell dan echinocytes. ${ }^{14}$ disebabkan oleh perubahan metabolik yang terjadi karena kondisi yang berbeda dari kondisi in vivo, yaitu perubahan dalam kerentanan ATP dan DPG, penurunan $\mathrm{pH}$ darah, peningkatan kalium dan konsentrasi laktat, perubahan dalam bentuk sel eritrosit, hilangnya viabilitas eritrosit dan hemolisis. Hal ini sesuai dengan teori yang menyatakan bahwa eritrosit membutuhkan ATP dalam mempertahankan kelangsungan hidupnya. Penurunan kadar ATP akan menyebabkan lipid membran rusak, akumulasi natrium dan kalsium intraseluler, penurunan potassium dan kadar air instraseluler, dehidrasi sel, membran kaku dan mudah pecah. Dehidrasi sel ditunjukkan oleh peningkatan bentuk crenated cell, dan sel-sel yang kaku dan mudah pecah 
seperti yang ditunjukkan oleh peningkatan bentuk echinocytes. ${ }^{15,16}$ Dan pada penelitian ini ditemukan bahwa artefak yang terbentuk yakni ditemukannya crenated cell dan echinocytes.

Perubahan eritrosit dari bentuk diskoid menjadi sphero-echinocytes diawali dengan echinocytes yang kemudian akan berubah bentuk menjadi bola crenated dengen beberapa spikula yang disebut spheroechinocytes, dan dengan penyimpanan yang lebih lama akan membentuk spherocytes. ${ }^{17}$ Hal tersebut terbukti, hasil penelitian ini menunjukkan selama penyimpanan ditemukan bentuk sphero-echinocytes. Morfologi eritrosit dapat mengalami perubahan degeneratif pada Sediaan Apus Darah Tepi (SADT) disebabkan oleh penyimpanan darah dan karena adanya antikoagulan atau media pengawet. ${ }^{18}$ Hal tersebut sesuai dengan penelitian ini dimana PRC disimpan dalam Alsever Komersial dan Buatan selama waktu tertentu mengalami perubahan morfologi eritrosit.

Penelitian ini menemukan bahwa penyimpanan PRC dalam Alsever Komersial pada pemeriksaan morfologi eritrosit dapat bertahan atau tidak terdapat perbedaan hingga penyimpanan hari ke-20. Seperti yang tercantum pada penelitian Alsever, dkk $^{19}$ bahwa larutan Alsever dapat memperpanjang hidup eritrosit. Dan hal ini sejalan dengan hasil pada penelitian sebelumnya ${ }^{10}$ yang menemukan bahwa PRC dalam Alsever Komersial pada indeks eritrosit masih stabil hingga hari ke-20.

Sedangkan penyimpanan PRC dalam Alsever Buatan terhadap morfologi eritrosit pada penelitian ini ditemukan bahwa masih stabil hingga penyimpanan hari ke-15 tetapi mulai terdapat perbedaan pada penyimpanan hari ke-20. Hasil tersebut tidak sesuai dengan penelitian sebelumnya yang mengatakan bahwa PRC dalam Alsever Buatan yang diperiksa menggunakan hemanalyzer untuk parameter MCV masih stabil hingga hari ke-18 secara statistik, sedangkan parameter lainnya seperti nilai hemoglobin, hematokrit, jumlah eritrosit, nilai $\mathrm{MCH}$ dan $\mathrm{MCHC}$ masih stabil hingga hari ke-20 secara klinis. Perbedaan hasil tersebut dapat diakibatkan oleh beberapa faktor, salah satunya adalah perbedaan pembacaan hasil perhitungan morfologi eritrosit. Pada penelitian ini pembacaan hasil menggunakan SADT yang diamati secara mikroskopis, dimana hasil perhitungannya sesuai formasi bentuk abnormal eritrosit (crenated cell dan echinocytes), sedangkan pada penelitian sebelumnya menggunakan alat otomatis hemanalyzer, dimana interpretasi hasil dari alat yang membaca seluruh morfologi eritrosit baik normal maupun abnormal tetap dihitung, sehingga hasilnya dapat normal atau lebih stabil dibandingkan hasil pembacaan pada SADT.

Selain itu, faktor yang berpengaruh terhadap hasil morfologi eritrosit menggunakan SADT adalah pembuatan Alsever yang kandungan zat/larutan isotonik di dalamnya tidak sesuai dengan satndar $(2,05 \%$ glukosa, $0,42 \%$ natrium klorida, $0,8 \%$ trisodium sitrat, 0,055\% asam sitrat, dalam $1 \mathrm{~L}$ air suling steril). ${ }^{19}$

Lama fiksasi dalam pembuatan SADT juga dapat berpengaruh pada hasil morfologi eritrosit. Seperti yang disebutkan dalam jurnal lain bahwa terdapat pengaruh yang bermakna lama penguapan larutan fiksasi terhadap hasil mikroskopis krenasi pada SADT. Hal ini terjadi karena eritrosit yang dimasukkan dalam larutan hipertonis, maka tekanan osmosis akan terjadi dari dalam ke luar sel yang akan menyebabkan sel mengalami krenasi atau pengerutan, sedangkan apabila eritrosit berada dalam lingkungan yang hipotonis, maka osmosis akan terjadi dari luar ke dalam sel yang dapat menyebabkan sel menggembung hingga menjadi echinocytes. ${ }^{20}$ ICSH 
(International Council fo Standarization in Haematology) pun merekomendasikan agar pembuatan SADT harus dilakukan kurang dari 4 jam. ${ }^{21}$ Selain itu, echinocytes terbentuk dapat disebabkan oleh keterlambatan dalam pembuatan preparat atau karena penyimpanan yang lama. ${ }^{22}$

Pada penelitian ini didapat hasil terjadinya peningkatan fragilitas osmotik atau penurunan daya tahan eritrosit pada PRC yang disimpan dalam beberapa variasi waktu. Begitupun setelah dievaluasi menggunakan uji statistik Wilcoxon fragilitas osmotik terdapat perbedaan yang signifikan seiring dengan semakin lamanya waktu penyimpanan. Hal ini sesuai dengan hasil penelitianpenelitian sebelumnya. ${ }^{13}$ Namun, pada beberapa konsentrasi $\mathrm{NaCl}$ terdapat hasil yang menurun saat disimpan dengan waktu yang lama. Hal tersebut dapat terjadi karena selama penyimpanan PRC terdapat beberapa perubahan pada kondisi eritrosit, salah satunya kemungkinan terjadinya lisis yang lebih banyak atau sedikit, dimana kondisi sel eritrosit antara satu dengan yang lainnya berbeda, sehingga kemungkinan terjadinya lisis antara eritrosit satu dengan yang lainnya berbeda. $^{13}$

Penelitian ini menemukan bahwa penyimpanan PRC dalam Alsever Komersial pada pemeriksaan fragilitas osmotik dapat bertahan dari hemolisis atau tidak terdapat perbedaan hingga penyimpanan hari ke-20, dengan nilai rata-rata resistensi maksimum $0,324 \%$, dimana hasil ini masih dalam batas normal. Hal ini menunjukkan bahwa hemolisis total terjadi pada rata-rata konsentrasi $\mathrm{NaCl}$ 0,324\%. Hasil tersebut sejalan dengan hasil pada penelitian sebelumnya yang menemukan bahwa terdapat perbedaan yang signifikan terhadap nilai fragilitas osmotik pada PRC yang disimpan selama 42 hari, yaitu mulai penyimpanan hari ke-21.
Sedangkan penyimpanan PRC
dalam Alsever Buatan terhadap fragilitas osmotik pada penelitian ini ditemukan bahwa masih dapat bertahan dari hemolisis hingga penyimpanan hari ke-15 tetapi mulai terdapat perbedaan pada penyimpanan hari ke-20 dengan nilai rata-rata resistensi maksimum 0,38\%, dimana hasil ini telah melebihi batas normal. $\mathrm{Hal}$ ini menunjukkan bahwa hemolisis total terjadi pada rata-rata konsentrasi $\mathrm{NaCl} 0,38 \%$.

Penelitian lain $^{23}$ menyatakan bahwa kehilangan membran dapat terjadi selama penyimpanan eritrosit, yang mengakibatkan eritrosit memiliki bentuk yang lebih bulat (sphero), memiliki sedikit membran dan mudah lisis dengan kekuatan osmotik yang relatif tinggi. Hal tersebut sesuai dengan hasil yang ditemukan pada pemeriksaan morfologi eritrosit, yaitu terbentuknya echinocytes yang mempunyai bentuk lebih bulat dibandingkan eritrosit normal. Bentuk sel sphero ini memiliki area permukaan membran yang lebih sedikit untuk menyerap air sebelum mengalami lisis, sehingga menyebabkan eritrosit dengan bentuk sphero mudah lisis. Kondisi tersebut disebut dengan penurunan resistensi atau peningkatan fragilitas osmotik. ${ }^{24}$

Faktor lain yang dapat berpengaruh terhadap hasil fragilitas osmotik juga disebutkan dalam studi lain bahwa hemolisis eritrosit akan meningkat seiring dengan waktu penyimpanan. Efek yang timbul dari penyimpanan darah adalah perubahan yang signifikan dalam integritas membran eritrosit. Adanya leukosit dalam suspensi eritrosit juga dapat berkontribusi secara signifikan terhadap peningkatan hemolisis selama penyimpanan. Leukosit akan memecah dan melepaskan sejumlah bahan kimia dan enzim seperti hidrogen peroksida dan protease. Protease tersebut dapat menyebabkan eritrosit lisis selama 
penyimpanan, dan kelangsungan hidup eritrosit semakin cepat. ${ }^{25}$

Penelitian lainnya mengatakan bahwa peningkatan fragilitas osmotik eritrosit berhubungan dengan peningkatan suhu yang menyebabkan stres eritrosit. ${ }^{26} \mathrm{Di}$ samping itu, jurnal lain menyatakan bahwa suhu merupakan faktor utama dalam kerapuhan eritrosit yang kemudian menghasilkan resistensi hingga hemolisis yang meningkat seiring dengan bertambahnya suhu. ${ }^{27}$

Berdasarkan hasil morfologi eritrosit dan fragilitas osmotik pada penyimpanan PRC dalam Alsever Komersial dan Buatan pada penelitian ini menandakan bahwa kualitas larutan Alsever Komersial lebih baik dibandingkan dengan Alsever Buatan. $\mathrm{Hal}$ ini dapat dipengaruhi oleh pengelolaan dan/atau pengolahan larutan tersebut, misalnya sterilisasi Alsever Komersial lebih baik dibandingkan Alsever Buatan, perbedaan konsentrasi kandungan komponen antara Alsever Komersial dan Buatan seperti $\mathrm{NaCl}$ yang berpengaruh terhadap larutan isotonik, serta kemungkinan terdapat perbedaan komponen seperti adanya penambahan Natrium Azida dalam Alsever Komersial.

\section{SIMPULAN}

Terdapat pengaruh antara lama penyimpanan PRC dalam Alsever Buatan terhadap morfologi eritrosit dan fragilitas osmotik.

Disarankan penelitian lanjutan mengenai kestabilan PRC dalam Alsever dengan variasi waktu yang berbeda untuk mengetahui pada hari ke berapa tepatnya mulai terdapat perbedaan yang signifikan di antara penyimpanan hari ke-15 hingga 20 pada Alsever Buatan, dan di antara penyimpanan hari ke-20 hingga 25 pada Alsever Komersial terhadap morfologi eritrosit dan fragilitas osmotik, dengan menggunakan metode yang lebih sensitif dan kuantitatif, seperti metode spektrofotometri untuk fragilitas osmotik.

\section{DAFTAR RUJUKAN}

1. D'Alessandro, A., Kriebardis AG., Rinalducci S. 2015. An update on red blood cell storage lesions, as gleaned through biochemistry and omics technologies. Transfusion, Vol 55, No 1: 205-219

2. Zimring, JC. 2015. Established and theoretical factors to consider in assessing the red cell storage lesion. Blood, Vol 125, No 14: 2185-2190

3. Antonelou, MH., dkk. 2012. Effects of pre-storage leukoreduction on stored red blood cells signaling: a time-course evaluation from shape to proteome. Journal of Proteomics, Vol 76: 220-238

4. Kor, DJ., Buskirk CMV., Gajic O. 2009. Red Blood Cell Storage Lesion. Bosnian: Journal of Basic Medical Sciences, Vol 9: 21-27

5. Cluitmans, JCA., dkk. 2012. Red Blood Cell Deformability During Storage: Towards Functional Proteomics and Metabolomics In The Blood Bank. Blood Transfuse, Vol 10: 12-18

6. Blasi, B., dkk. 2012. Red Blood Cell Storage and Cell Morphology. Journal of the British Blood Transfusion Society, p: 90-96

7. Daryl, J., Camille M., Ognjen G. 2009. Red Blood Cell Storage Lesion. Bosnia: Bosnian Journal of Basic Medical Sciences, Vol 9, No 1: 21-27

8. Deyhim, MR., dkk. 2014. Alternation in Erythrocyte Enzyme Antioxidant Activity During Blood Storage. Iranian: Journal of Blood and Cancer, Vol 6, No 2: 69-74

9. Sigma-Aldrich, Inc. Produk Information Sigma Alsever's Solution

10. Aulia, Hanum Maulida. 2018. Uji Stabilitas PRC Dalam Larutan Alsever Buatan Ditinjau Dari Kadar Hemoglobin, Nilai Hematokrit, 
Jumlah dan Indeks Eritrosit. Bandung: Jurusan Analis Kesehatan Poltekkes Kemenkes RI Bandung

11. Binus, University. 2015. Sign Wilcoxon Test. Diakses di https://sbm.binus.ac.id/2015/11/21/ sign-wilcoxon-test/ pada tanggal 12 Juni 2019

12. Dewi, Sri Kartini., Rachmawati Muhiddin., Mansyur Arif. 2015. Gambaran Morfologi Eritrosit di Packed Red Cells Simpan). Clinical Pathology and Medical Laboratory, p: $100-106$

13. Ica, Nurul Nur Azizah. 2018. Stabilitas Penyimpanan Darah K2EDTA Pada Pemeriksaan Morfologi Eritrosit Dan Fragilitas Osmotik. Bandung: Jurusan Analis Kesehatan Poltekkes Kemenkes RI Bandung

14. Ugurel, Elif., dkk. 2017. Blood Storage Alters Mechanical Stres Responses of Erythrocytes. Clinical Hematology and Microcirculation, p: $143-155$

15. Prihartini, D. 2011. Types of Blood Components and Their Administration Indications. In: Blood Transfusion Basics. Jakarta: Medical Faculty Publisher of Padjajaran University, p: 40-54

16. Bain, BJ., Lewis SM. 2012. Basic Haematological techniques. In: Practical Haematology Eleventh Ed. London: Churcill Livingstone Elsevier, p: 41-42

17. Cora, Michelle C., dkk. 2012. Atifactual Changes in SpragueDawley Rat Hematologic Parameters After Storage of Samples at $3^{\circ} \mathrm{C}$ and $21^{\circ} \mathrm{C}$. Journal of the American Association for Laboratory Animal Science, Vol 51: 616-621

18. Dacie, Sir John V., S. M. Lewis. 1994. Practical Hematology eight edition. Hongkong: Churchill Livingstone
19. Alsever, J.B., Ainslie R. 2002. Product Information Alsever's Solution. New York: J.Med

20. Pasini, EM., dkk. 2006. Blood. Washington DC: The American Society of Hematology

21. Tatsumi, N., S Miwa., S. M. Lewis. 2002. Specimen Collection, Storage, and Transmission to the Laboratory for Hematological Tests: International Society of Hematology and the International Council for Standarization in Haematology. International Journal of Hematology, Vol 75: 261-268

22. Bain, Barbara J. 2011. Blood Cell Morphology in Health and Disease. Elseiver Ltd, p: 69-99

23. Beutler, Ernest., Wanda Kuhl., Carol. 2018. West The Osmotic Fragility of Erythrocytes After Prolonged Liquid Storage and After Reinfusion. Vol 59

24. Muhammad, Adang., Usi Sukorini. 2004. Profil Pemeriksaan Fragilitas Osmotik Eritrosit di RS. Dr. Sardjito. Mutiara Medika, Vol 4, No 2

25. Walski, Tomasz., dkk. 2014. Individual Osmotic Fragility Distribution: A New Parameter for Determination of the Osmotic Properties of Human Red Blood Cells. BioMed Research International, Vol 6

26. McGowan., Catherine M., David R. 2014. Hodgson Chapter 5Hematology and Biochemistry. The Athletic Horse (Second edition) Principle and Practice of Equine Sports Medicine, Vol 56-68

27. Richieri, Gary V., Howard C. 1985. Temperature Effect on Osmotic Fragility and the Erythrocyte Membrane. Biochimica et Biophysica Elsevier, p: 41-50 